\title{
Food Intake to Overweight and Obesity in Children Aged 7-12 Years at Kabupaten Aceh Barat
}

\author{
${ }^{1}$ Sri Wahyuni Muhsin, ${ }^{2}$ Sukma Elida, ${ }^{3}$ Arif Iskandar \\ ${ }^{1}$ Public Health Faculty, Teuku Umar University, Meulaboh, Indonesia, sriwahyunimuhsin@utu.ac.id \\ ${ }^{2}$ Public Health Faculty, Teuku Umar University, Meulaboh, Indonesia, sukmaelida@utu.ac.id \\ ${ }^{3}$ Public Health Faculty, Teuku Umar University, Meulaboh, Indonesia, arifiskandar@utu.ac.id \\ Coresponding author : Sri Wahyuni Muhsin, e-mail : sriwahyunimuhsin@utu.ac.id
}

\begin{abstract}
Nutrition problems in Indonesia are already classified as multiple nutritional problems, namely the problem of undernutrition and overweight obesity. In 2010 the prevalence of overweight and obesity in Aceh province was 11.2 percent and in 2013 was 14.8 percent (8.9 percent fat and 5.9 percent very fat) resulting in an increase of 3.6 percent. Food intake is one factor that can cause cause overweight and obesity. This study wanted to analyze the factors of food intake in children aged 7-12 years become the cause of overweight and obesity. This study was an observational analytic study with cross sectional design aimed at assessing relationship of food intake on obesity-related weight status in first-fifth grade elementary school children aged 7-12 years at Kabupaten Aceh Barat. The sample size is 289 students. Determination of child obesity status using Body Mass Index based on Age (IMT/U), that is overweight and obesity if IMT/U>1.0 SD. Data of food intake was obtained through interview using 24-hour food recall form for 3 days. From 289 respondents, 51.90\% were overweight and obesity. Factors related to the incidence of overweight and obesity are energy and fat intake (OR $=4.56$ and 4.03).
\end{abstract}

\section{ARTICLE INFORMATION}

Submitted: $18 / 01 / 2020$

Revised: $10 / 02 / 2020$

Accepted: 21/04/2020

Published Online : 15/05/2020

\section{Keywords:}

Food Intake

Energy

Fat

How to cite this article: Muhsin, S. W., Elida, S., Iskandar, A. (2020). Food intake to Overweight and Obesity in Children Aged 7-12 Years at Kabupaten Aceh Barat. JNS : Journal of Nutrition Science, 1(1), 11-13.

\section{Introduction}

Overweight and obesity are excessive fat accumulations that can interfere with health. Obesity is a malnutrition disease that comes from the quality of an unhealty diet and abnormal body composition disease (Gitnerr, 2014).

The problem of obesity in shool-age is still high at 18.8 percent (Riskesdas, 2013). In Aceh there was an increase in overweight and obesity in 2010 and 2013 which was 11.2 percent to 14.8 percent. Of the 23 districts in Aceh, Kabupaten Aceh Barat had a higher very fat prevalence over provincial rates.

Factors that affect the incidence of obesity include daily living habits, such as diet, physical activity, and sleep patterns and will trigger some disease, physical and psychological problems, and social isolation in children.
Children who often consume fast food will be obese by 3.28 percent (Badjeber, F., Kapantouw, NH, Punuh, M, 2009). The level of excess energy sufficiency has a 6.9 times higher chance of becoming obese compared to a group of students with a good level of energy adequacy (Pampang, E., Purba, Br,P., Huriyati, E, 2009).

The influential food intake, especially those containing high calories and fat (Yussac, M.A.A. 2007) The Aceh region is synonymous with foods that have high calories and fat.

Changes in eating patterns and physical activity can be due to an increase in income in certain socioeconomic groups. Obesity is often associated with high-income people. Changes in culture, attitudes, behaviors and lifestyles, eating patterns, as well as increased incomes influence the choice of types and amounts of food consumed (Hidajat Boerhan, 2010). 


\section{Method}

The research method used was a quantitative study. The dependent variables in this study were the incidence of overweight and obesity. Independent variables is food intake factors associated with obesity. The sample in this study were elementary school children aged 7 to 12 years old in 12 selected primary schools and who met the inclusion and exclusion criteria. The sample size is 289 samples and the sampling technique is simple proportional sampling. Determination of child obesity status using Body Mass Index based on Age (IMT/U), that is overweight and obesity if IMT/U>1.0 SD. Data of food intake was obtained through interview using 24hour food recall form for 3 days. The analysis used bivariate (chi square).

Energy intake

Less $\quad:<80 \%$ AKG Energi

Normal : 80-110\% AKG Energi

More : $\quad>110 \%$ AKG Energi (WNPG, 2004)

Fat intake

Less $\quad:<80 \%$ AKG Energi

Normal : 80-110\% AKG Energi

More : $>110 \%$ AKG Energi (WNPG,

2004)

\section{Results}

T In Table 1 it can be seen that the proportion of respondents who are overweight and obese in the group of children with excess energy intake is $90.91 \%$ and is greater than in the group of children with less and normal energy intake. Likewise with fat intake, respondents with more fat intake and are overweight and obese as much as $61.95 \%$ (127 respondents) and statistically significant with a $p$ value $<0.001$.

Tabel 1. Hubungan asupan makanan dengan kejadian overweight dan obesitas

\begin{tabular}{|c|c|c|c|}
\hline Variabel & $\begin{array}{l}\text { Overweight } \\
\text { dan } \\
\text { Obesitas } \\
(\mathrm{n}=150)\end{array}$ & $\begin{array}{l}\text { Normal } \\
(n=139)\end{array}$ & $\begin{array}{l}\text { Total } \\
(\mathrm{n}=289)\end{array}$ \\
\hline \multicolumn{4}{|l|}{$\begin{array}{l}\text { Energy } \\
\text { intake }\end{array}$} \\
\hline $\begin{array}{l}\text { More } \\
(>110 \%)\end{array}$ & $30(90,91)$ & $3(9,09)$ & $33(100,00)$ \\
\hline $\begin{array}{l}\text { Normal } \\
110 \%)\end{array}$ & $81(68,64)$ & $37(31,36)$ & $118(100,00)$ \\
\hline Less $(<80 \%)$ & $39(28,26)$ & $99(71,74)$ & $138(100,00)$ \\
\hline \multicolumn{4}{|l|}{ Fat intake } \\
\hline
\end{tabular}

More $(>110 \%)$

Normal $\quad(80-\quad 21(28,77) \quad 52(71,23) \quad 73(100,00)$ $110 \%)$

Less $<80 \%) \quad 2(18,18) \quad 9(81,82) \quad 11(100,00)$

The level of energy intake is obtained from the results of comparing the energy intake of children with the AKG in 2013 which is recommended according to WNPG (2004) by considering age and gender factors. Energy and fat intake is also a faktor obesity. Normal energy intake is a comparison between more and less energy intake. From the analysis it can be seen that children who have more energy intake have a 4.56 times greater risk of being overweight and obese compared to those with less energy energy intake with a value of $p=0.01$.

\section{Discussion}

From research result, if seen from the proportion of total energy intake in the study this, amounting to $47.75 \%$ of respondents energy intake included in the group less. This is also possible to be caused by external factors, namely parental genetic factors. This is also supported by the results of research (Humaroh, 2013) stated that children with excessive diet had 3.2 times greater risk of becoming obese than children with normal diet.

The results of a study in South Sumatra which explained that the proportion of obese children who consume more energy categories is more, because the Province is a food storage area and accustomed to consuming food sources of energy. Just like the area, Aceh is also synonymous with staple foods such as rice, meat and fish.

Excess fat intake can also increase the prevalence of children to obesity 4.03 times compared to children with less fat intake. Increasing consumption of high fat foods will increase the BMI of children because high-energy and fatty foods also

$\mathbf{P}$ have a(0Rre the can increase appetite and cause excessive consumption (Budiyanti, 2011)

In this study, the types of food that contributed the most energy were snacks such as fried foods and fast food. High-energy and fatty foods also have a more delicious taste so that it can increase appetite and cause excessive consumption (Hidayati, N.S., Irawan, R., Hidayat B, 2005). Children who are $0,01 \%$ verweight and ${ }^{1}$ obese are caused by consuming more meat, fried foods $24 \mathrm{ver}$ the past week (Zhang, T et al, 2016). As food recalled interview results stated that respondents consume food and snacks sold around

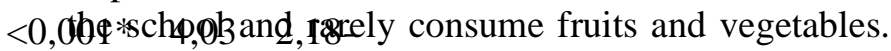
Yussac et al. (2007) stated that influential food 
intake, especially those containing high calories and fat.

This research was also supported by Van den Berg et al. (2011) which states that excess energy intake in a long time can cause overweight. ${ }^{10}$ The results of Gibson and Neate's research (2007) in the United Kingdom also stated that children who consume foods high in protein and fat will increase the risk of nutrition more than doubled (Gibson, S dan D. Neate, 2007). Precisely the normal status has more energy intake than the obese (Ansokowati research, 2014).

Likewise with the results of the study of Zhang et al., (2016) in China that the more dominant influence on the incidence of obesity is not food such as meat and fast food, but the intake of drinks that contain lots of sugar is 1.39 times more likely for children to be obesity.

\section{Conclusion}

There is a significant relationship between food intake (energy and fat) with the incidence of overweight and obesity

\section{Acknowledgement}

The researcher would like to thank the Head of the All person who helped during the data collection process in this study.

\section{Author Contribution and Competing Interest}

During the process of collecting, processing and analyzing data to the interpretation of all writers, they contributed and ensured that there were no conflicts of interest related to this text.

\section{Publisher's Note}

JONS : Jurnal Of Nutritien Science remains neutral with regard to jurisdictional claims in published institutional affilition.

\section{References}

Ansokowati, A.P. (2014). Asupan energi, presentase energi dari karbohidrat-lemak dan status overweight dan obesitas remaja SMS Negeri Kota Yogyakarta. Tesis. Pascasarjana UGM

Badjeber, F., Kapantouw, NH., Punuh, m. 2009. Konsumsi Fast Food Sebagai Faktor Risiko
Terjadinya Gizi Lebih pada Siswa SD Negeri 11 Manado. Jurnal Manado; Universitas Sam Ratulangi.

Berg, S.W.Van Den, Boer, J.M.A., Scholtens, S., jongste, J.C.De, Brunekreef, et al. 2011. Quantification of the Energy gap in Young Overweight children. The PIAMA birth cohort study. BMC Public Health, 11, 326

Budiyanti. 2011. Analisis faktor penyebab obesitas pada anak usia sekolah di SD Islam Al-Azhar 14 Kota Semarang. Tesis

Hidajat Boerhan. 2010. Obesitas. UNIMUS. Semarang baya

Hidayati, N.S., Irawan, R., Hidayat B. 2005. Obesitas pada anak, Bagian Ilmu Kesehatan Anak, Fakultas Kedokteran Universitas Airlangga

Humaroh, Y. 2013. Faktor Sosial Determinan, Pola Makan, dan Aktivitas Fisik terhadap Kejadian Obesitas pada Anak Sekolah Dasar Kelas IV dan V di Kecamatan Tampan Kota Pekan Baru. Tesis. Program PAscasarjana UGM Yogyakarta

Huriyati, E. 2006. Studi Kohort Prevalensi Obesitas Siswa Siswi Sekolah Lanjutan Tingkat Pertama (SLTP) Kota Yogyakarta. Junal Gizi Klinik Indonesia, Vol 3. No.1, 1-4

Gibson, S dan D. Neate. 2007. Sugar Intake, soft drink consumption and body weight among british children : Futher analysis of National Diet and Nutrition Survey DataWith adjustment for under-reporting and physical activity. International Journal of Food Sciences and Nutrition, 58, 6. 445-460

Gittner, L.S. 2014. Obesity Prevention in Children from Birth to Age 5. Primary Prevention Insight, (4), 1-10

Pampang, E., Purba, Br, P., Huriyati E. 2009. Asupan energy, Aktivitas Fisik, Persepsi Orangtua dan Obesitas Siswa SMP, Jurnal Gizi Klinik Indonesia, Vol 5. No 3, 108-113

Yussac, M.A.A. 2007. Prevelensi Obesitas pada Anak Usia 4-6 tahun dan Hubungannya dengan Asupan Serta Pola Makan. Majalah Kedokteran Indonesia 57 (2) : 47-53

Zhang, T., Cai, L., Ma, L., Jimh, J., Chen, Y., \& Ma, J. 2016. The prevalence of obesity and influence of early life and behavioral factors on obesity in Chinese children in Guangzhou, BMC Public Health : 16-954 